\title{
BLINDED BY THE LIGHT \\ -- OR HOW NATURE TRIUMPHED OVER NURTURANCE
}

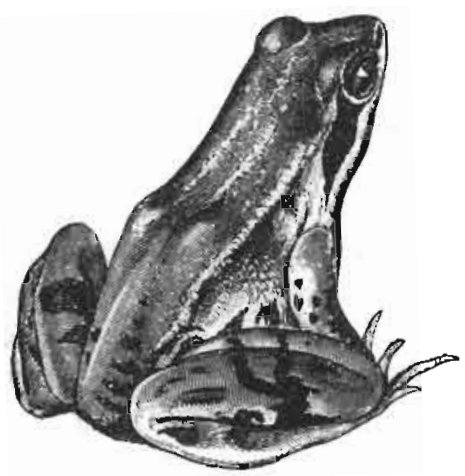

is the process by which one is sensitized to the feelings of others maturation or rejuvenation? If it is through maturity that we become more compassionate, then what of the natural empathy of the child? My own journey towards "enlightenment" has taken me not forward but in a circle: back towards the child who loved freely and shared the emotions of parents, siblings, birds, dogs, and frogs. A chlld who had not yet been distorted by cultural prejudices--whose sense of self didn't require disconnection from others. Not that people are innately perfect. Like all animals, human beings have certain instincts and raw emotions. Humans can be violent and selfish. As we mature, we presumably learn to control these negative impulses. But, almost invarlably, many positive qualities are lost in the process, and the unique potential of the human psyche is diminished.

The most powerful of my earliest memories involve animals. There was the day our parakeet died. Though I hadn't had any special rapoort with "Chippy" (he pecked at my fingers whenever I was so bold as to make some frlendly overture), I was profoundly upset at seeing him dead at the bottom of his cage, and was only calmed down when a funeral was staged by my older brother in the backyard.

I must have been about four or flve when a German shepherd puppy was placed with me in the back seat of my mother's car. I was quite alarmed at the sudden presence of this strange creature, but

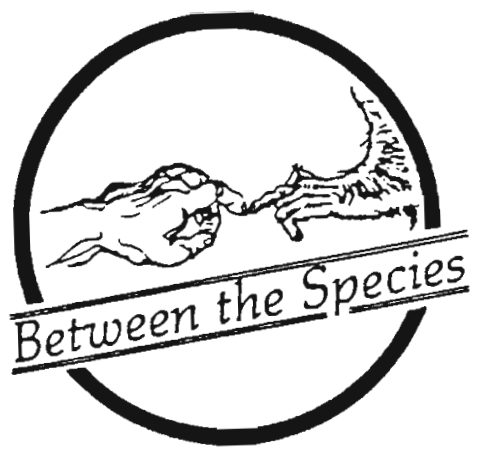

the fear changed to wonder by nightfall, and "Silver" was soon an integral part of the family. I remember when she was scolded for vomiting in my great aunt's living room, and how I crawled under the table to comfort her. I could see she was ashamed.

I remember the horned toads and frogs my brother used to catch and bring home. I played with them as he did. One day, however, I must have been told that girls are afraid of frogs and toads and lizards, for suddenly instead of reaching out to touch them, I recolled in disgust at the sight of them. As an adolescent, I screamed with all the other girls when boys shoved them in our faces or tried to drop the poor creatures down our dresses.

The thought of frogs brings up more painful memories, too. Of a time my father took my brother frog-gigging. I looked out of our glass patio door one summer evening to see my father cutting the head off a huge bullfrog. There were several mutilated bodies on the grond around $\mathrm{hlm}$, and blood everywhere. I began crying and ran to my room. My father later tried to comfort me, but 1 thought him a monster. Though I tried to reconcile the image of him butchering frogs with memories of the loving daddy he had always been, never did he regain the hero status he held before. And despite all the things

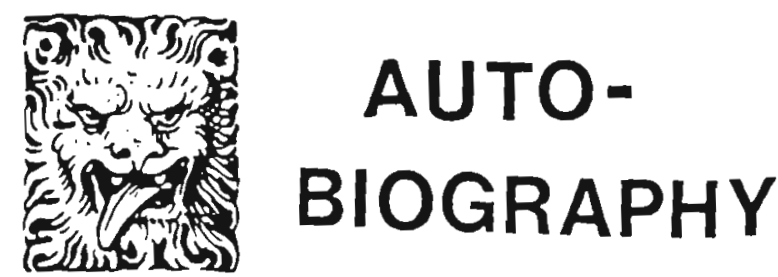


he's done since that have caused me distress or dissatisfaction, nothing has caused such a loss of admiration as that one incident.

It must have been a little before the frog-gigging that my brother announced that what I was eating had once been a cow. I didn't belleve him--not at all-and asked my mother to make him stop saying it. instead, she startled me with the truth. Yes, hamburger comes from a cow. And chicken is really a chicken, bacon is part of a pig, and so on. I cried easily and frequently as a child, and this unpleasant news provoked a storm. The exact chronology of the following events escapes me now, but what I next recall is sitting in my father's lap, hearing a mixedup version of the "survival of the fittest" theory. I understood what my father was saying when he told me human beings had to eat meat to survive. My mother stood by and reassured me that it was so. It was God's plan.. Animals don't suffer when they're killed. Though I wondered for years what a "fittest" was, the essence of my parents' message got through: like it or not, I had to eat meat. And for many years I did, though I was never comfortable with it. I steadfastly refused to eat any animals I hadn't already eaten when I learned the facts. I ate cows, pigs, sheep, birds, and figh regularly, but never would I touch rabblt, venison, or other "game." And I couldn't eat meat if it was attached to the whole animal. A roasted suckling pig at a party upset me so I made a scene and insulted the hosts.

My mind was divided into "rooms," and many of them were locked. A major dream motif throughout those years was discovering an old abandoned house, strange but oddly famillar, with dark winding staircases and hidden rooms. My inconsistencies went way beyond food, too. My complete fallure to consciously recognize fur as animal skin astonishes me now. Rabbits were among my favorite animals, and because of this affection, I treasured toys and garments made of real rabblt fur. My mother had fur coats and stoles, and I remember how good they all felt and smelled. I was proud when she thought me grown up enough to wear her furs on formal dates, and was thrilled to receive a beaver jacket from her as a high school graduation present. Yet my mother was an "animal lover." We were all "animal lovers." We had been carefully taught that "overything has feelings," and that it was wrong to "cause suffering." When you kill animals, you do it "quick" so they don't feel any pain. Every one we ate and wore had been "humanely" dispatched. It was quite a comfort to me.

Still, I couldn't dissect the worm, frog, and turtle placed in front of me in tenth-grade biology. While I had no doubt they had all been subjected to a "quick and painless" death, there was something wrong about cutting them up, though I didn't know what. It felt bad. I couldn't articulate my feelings. so I just sat on my stool and gave the teacher a blank look when she passed by. She didn't say mything, didn't force me to do it. It was a relief when biology was over.

By the time I finished high school, I was so deadened that I actually went dove hunting with some friends of my parents in south Texas, down by the Mexican border, where Labor Day is celebrated by shooting the migrating birds. I didn't kill any myself; other than ingects, I've never had the nerve to kill any animal myself. Even when I went fishing with my grandfather in Tennessee, he had to do the dirty work. I just watched as birds fell out of the sky, and helped pick them up. If they weren't dead yet, I took them to some man who'd twist off their heads. I remember thinking how ghastly it was and wondering why i felt nothing

Shortly after the "hunt" I went to a bullfight across the border. Nothing registered but the music The blood didn't seem real. I justified the carnage later by thinking it wasn't any worse for the bull than going to the slaughterhouse. That's what I told people who questioned how such an "animal lover" as myself could go to a bullifight.

1 married at age 22. A few months afterwards, on a Saturday afternoon, I recelved a piece of mail from The Fund for Animals. It was about fur and contained some sad little poems and pictures of a fox and rabbit caught in leghold traps. The look in their eyes plerced my soul. Animals just like these had been killed for furs I had worn. It couldn't be denied. I sat down and cried...cried hard. I sold my fur and gave the money to The Fund and a local humane society. From then on, friends and relatives wearing fur were unwelcome in my home. I couldn't see a fur without experiencing shortness of breath and an adrenaline surge. 
I got more mail from The Fund and other animal welfare groups. Soon I was trying to save the whales and all the other animals by writing letters to newspapers, members of Congress, and government officials worldwide. Gradually I became involved with local animal sheiters, helping them with special events mostly - not actually helping in the shelters. That takes more guts than I have even now. My weakness in that regard gives me great respect for the people who have the strength needed to work directly with abused and abandoned animals...to kIll those you love so much.

I had always wanted a dog of my very own. On Good Friday, 1972, my mother drove me to see a German shepherd puppy. Bred to be a show dog, he was not three months old and dreadiully shy. Not only did that disqualify him for the ring, one ear wouldn't quite stand up. He looked more like an Afghan hound than a German shepherd, I thought, and he peed on himself every time anyone went near him. But I had gone to get a puppy and didn't have the heart to reject him. Once home, "Nicky" dashed onto the bed and stayed there most of the weekend. My husband was unimpressed with this add, cowering creature, but he was fond of animals and tried to make friends. Soon there was affection between them, but Nicky clearly belonged to me and, before long, I to him. The following spring a little blonde stray wandered up and joined the family. "Sally" became Nicky's dog.

Nicky grew into a beautiful animal, though his ear never straightened up. He had a long and heavy coat, black and red and brown. Despite a deep bark and ferocious appearance, Nicky remained shy--a sheep dog who was really a sheepish dog, we'd say. He was wolflike in his devotion to me, and the love was returned. Nicky was more important to me than anyone ever had been.

My husband knew he was second fiddle to a dog. To his credit, he never resented Nicky or the other anlmals. So, when It came, the divorce had nothing to do with animal rights. In fact, he was intelleclually ahead of me in many ways. He often questioned the assumption of human superiority over animals and didn' $t$ think it a good thing to eat a lot of meat. The marriage broke up over less important things. One day I took the dogs and left. I was 32 when the divorce became final and a new phase of life began.

I have often detected "synchronicity" in the important events of my life. Seemingly unrelated coincidences cause a change in course. Within a period of days I stumbled upon a little book that told "What's Wrong with Eating Meat?", discovered VEGETARIAN TIMES magazine, and received a direct mail piece from PETA asking me to stop eating animals. Now, I had never met a vegetarian before. Southeast Texas is hardly hotbed of radicalism. I had heard of vegetarianism, of course, but never understood that it might be a serious option. The prospect of swearing off meat was both alluring and frightening. I sensed its transformational power but imagined it would lead to all sorts of unpleasant things, such as intolerance of those who ate meat (everyone I knew at that time) and the end of a normal existence. I was right. It did. What I didn't suspect was the emotional vulnerability that would result ance I dismantled all the mechanisms of denial that allowed me to consume animals. Suddenly nothing was as it had seemed before. Nothing felt like it did before. Unobstructed empathy hurts.

A few weeks after I took the vegetarian vow my commitment was tested. An auto accident landed me in the hospital with a fractured pelvis. The pain was severe, and a head injury left me disoriented and stressed. I didn't feel like insisting on vegetarian meals and was tempted to drop the new regimen "temporarily." But I didn't, and the experience was empowering. I had proven something. Not eating meat was never difficult after that.

A couple of months after becoming a vegetarian some really bad times began. The night before Thanksgiving I came home to find Nicky, who was by then almost 12, having seizures. It was a stroke. After a few days of paralysis he began to recover somewhat. Though his doctor kept him on medicines, every few months another stroke would leave him more crippled. By Christmas of the following year he was a complete invalid. He was dying. I knew I should have him euthanized-the was deaf, he couldn't move, and he had to be forced to eat--but I couldn't let go of him. Finally one night he woke me up crying. He wouldn't stop crying. I knew it was the end. I called his doctor, who met me at the clinic at 2:00 a.m. Sally came with us; I wanted her to be there. "Yes, I know what has to be done," and 
"Yes, I want to be with him." I held him tight and as he went to sleep forever, he gave me one last kiss.

I had always known that losing Nicky would be dreadful. For years I had anticipated his death. But it was worse even than I imagined. The grief was shattering; it ruptured my psyche. I wanted to die. too, and wondered why I didn't just stop breathing. I don't think I would have withstood that period if it hadn't been for Sally and "Voltalre," a spotted white kitten adopted a few months earlier (mainly to cheer Nicky up). Like Sally, Voltaire had belonged to Nicky. They had been inseparable, and Voltaire mourned his absence with wailing crles. Sally, on the other hand, became withdrawn, and never quite recovered from her depression. As the grief burned down, I began to see animal work not only as my "cause" but as a tribute I could pay to Nicky. That way of looking at it released additional energy, and I was soon spending every free hour on animal rights. I started networking with activists nationally, and soon people like Don Barnes, Ingrid Newkirk, and Syndee Brinkman were speaking at Houston gatherings.

Greater involvement on the national scene began to shift my focus away from local activities. People began asking me to leave Texas to work for various animal rights organizations, but 1 declined. By the summer of ' 86 , however, I knew it was time for a big change. In June, Ingrid Newkirk, whom I idolized, persuaded me to open a California PETA office. Before moving to California I was to spend a month or so training in Washington, D.C. I arrived at PETA headquarters in late July--with Sally, Voltaire, and two additional cats, Gita and Shanti. But by late September I was on my way not to Callfornia but to Connecticut, Jim Mason, founder of THE ANIMALS' AGENDA, was leaving and I was asked to take his place. Working full-time in the humane movement is a mixed "blessing." Not only is it excruclatingly painful emotionally to deal with animal abuse every hour of the day, the intramovement politics are tough--especially at THE ANIMALS' AGENDA, where we must work with all the other animal groups as well as handle our own organizational affairs, It's like navigating a treacherous river. The current of issues and problems swirls around difficult personalities and egos.

The flip side to the negativity of humane work is knowing that one is doing something important with one's life. Most people can't say that. The process of liberating animals will surely civilize humanity. What we're doing is of historical--possibly evolutionary--significance. There's reason for optimism, too. In spite of our self-importance, Homo sapiens is a rather crude species. Millennia from now archaeologists will probably point to us as the "missing link" between our chimpanzee-like forebears and our descendants who, I believe, will have evolved into gentle, rational creatures. But even in our present state humans have unused potential for rationality and compassion. My own experience confirms it. We need enlightenment; we need to allow children to grow up without distortion.

My optimism isn't unqualified, however. There's a real possiblity that we may destroy the earth before we have a chance to change, and the danger is imminent.

For many years l've had a sense of a final conflict underway as this century, this millennium, ends. Is it a struggle of good versus evil? The ending of one age and the beginning of a better one? The emergence of something new out of the ashes of the obsolete? It doesn't matter how we visualize it. Something is in the air, and I' $m$ not alone in sensing it. At the ' 89 Alllance conference in Washington, Michael Klaper spoke of the next decade as the ten years left to us. He's counting the moons, he sald, knowing that each monthly cycle brings us closer to some planetary climax.

Yes, the next decade is critical. If we can only achleve the right focus and magnify the positive energy looking for an outlet through us. I believe the work of my generation will be successfully accomplished when this century closes. There will be lots left to do, of course--plenty of details to be worked out. But the "fever" will have broken, and the earth will begin to heal.

There's a New Year's Eve party planned for December 31, 1999, at the base of the pyramids in Giza, Egypt. I plan to be there. And if the next years are as propitious as I Imagine, I believe we'll see the beginning of a new epoch as the sun rises into the 21 st century.

THE END

(Which is always a preface to the future) 